\title{
The local knowledge of the plant names and uses by Semende tribe people in Kaur District, Bengkulu Province, Indonesia
}

\author{
WIRYONO^, YUSUF WANANDI, AISYAH KURNIA ILAHI, DESELINA, GUNGGUNG SENOAJI, \\ SISWAHYONO \\ Department of Forestry, Faculty of Agriculture, Universitas Bengkulu. Jl. WR Supratman, Kandang Limun, Bengkulu City 21170, Bengkulu, Indonesia. \\ Tel.: +62-736-21170; Fax.: +62-736-21290; `email: wiryonogood@unib.ac.id, wiryonogood@yahoo.com
}

Manuscript received: 10 December 2018. Revision accepted: 24 February 2019.

\begin{abstract}
Wiryono, Wanandi Y, Ilahi AK, Deselina, Senoaji G, Siswahyono. 2019. The local knowledge of the plant names and uses by Semende tribe people in Kaur District, Bengkulu Province, Indonesia. Biodiversitas 20: 754-761. Local botanical knowledge is essential for the survival of local communities, but there is a global trend of the loss of local botanical knowledge among young generation, which causes serious concern among ethnobotanists. The objectives of this study were: (i) to document the diversity of plant species locally utilized by the people of Semende tribe in Bengkulu, Indonesia, (ii) to know the correlation between botanical knowledge and age of those people, and (iii) to test whether their knowledge was affected by gender. Data were gathered through field observations and interviews with key informants and general respondents consisting of males and females, ranging from 16 to 60 years old. The data were analyzed qualitatively and quantitatively using regression analysis and t-test. The results showed that 106 species of plants were utilized by the people of Semende tribe for 14 types of uses. The knowledge of plant species and uses was positively correlated with age, implying that the young generation lost local botanical knowledge. Men had better botanical knowledge than women. Interaction with plants was presumably the determining factor affecting botanical knowledge. Young people spent less time in gardens than the elders, and so did the women than the men. Conversely, young people spent more time enjoying electronic entertainment than the elders, and so did the women than the men. Deliberate efforts must be done to maintain botanical knowledge among young people.
\end{abstract}

Keywords: Age, biodiversity, ethnobotany, gender, TEK

\section{INTRODUCTION}

For generations, people in rural areas have interacted with nature in their surrounding in search of food and other basic necessities, and to avoid dangers in order to survive. Their accumulative knowledge on nature, passed through generations and embodied in their culture, is called traditional ecological knowledge, usually referred to as TEK in literature (Berkes 1993; Pilgrim et al. 2008). TEK was not only important in the past, but it is still important today. TEK can be integrated with the conservation biology for a better practice of conservation (Drew and Henne 2006). With some limitations, TEK can also contribute to sustainable forest management (Rist et al. 2010) and ecological restoration (Uprety et al. 2012).

Part of TEK is local botanical knowledge, or the knowledge of plant names, ecology, and uses. Rural people use their botanical knowledge to meet their daily needs from plants. Villagers used 163 plant species for eight purposes in Banten (Wardah 2003), 83 plant species for eight purposes in Batu Ampar Village of South Bengkulu District (Wiryono and Lipranto 2013), and 79 species for ten purposes in Harapan Makmur Village, Central Bengkulu District (Wiryono et al. 2016). Karo ethnic in Semangat Gunung Village, North Sumatra, even used 109 plant species for food alone (Nisyawati et al. 2017) and in Poncokusumo district of East Java, local people used 181 species of plants just for medical purpose (Batoro and Siswanto 2017).
Because of plant importance in providing human needs, ethnobotanists around the world declared that ethnobotany is the science of survival (Aiona et al. 2007). It is, therefore, understandable that ethnobotanists have a great concern about the global trend of local botanical knowledge decline (Ramirez 2007; Aswani et al. 2018).

There have been reports on loss of botanical knowledge among the young generation in some countries, such as in Kolo District, Southwestern Niger (Ayantunde et al. 2008), in a horticultural village in Dominica (Quinlan and Quinlan 2007), in Zapotec communities in Mexico (Saynez-Vaquez et al. 2016), in Parnaíba Delta, Brazil (Sousa et al. 2012), in Central Bengkulu District, Indonesia (Wiryono et al. 2017), and in Subang District, West Java, Indonesia (Suryana et al. 2018). Many factors contribute to the loss of local botanical knowledge as well as TEK in general, such as modern education (Brosi et al. 2007; Saynez-Vaquez et al. 2016), the loss access to traditional resources (Turner and Turner 2008), and penetration of market economy (Godoy et al. 2005; Gómez-Baggethun et al. 2010)

The loss of TEK may have several consequences. In Argentina, due to lack of botanical knowledge, many poisonous plants are planted as ornamentental plants around kindergartens, increasing the risk of poisoning among children (Cuadra et al. 2012). The loss of TEK may cause food insecurity and diet diversity triggering diseases such as diabetes in local community, and it also threatens 
the community-based conservation efforts (Aswani et al 2018).

In Indonesia, there have been many studies on ethnobotany, but only few studies have been done on the loss of local botanical knowledge (Pilgrim et al. 2008; Putra et al. 2012; Wiryono et al. 2017; Suryana et al. 2018). Therefore, this kind of study should be conducted more often. This present study was conducted with the following objectives: (i) to record the diversity of plant species used by the people of Semende tribe in Kaur District, Bengkulu Province, Indonesia, (ii) to determine whether the botanical knowledge of those people was correlated with age, and (iii) to test whether gender affected the local botanical knowledge.

\section{MATERIALS AND METHODS}

\section{Study area}

This study was conducted in Tebing Rambutan Village, Nasal Sub-district, Kaur District, Bengkulu Province, Indonesia (Figure 1), from August to October 2018. The village is located near conservation forest, Bukit Barisan Selatan National Park, at the west coast of Sumatra, at altitudes of $25-100 \mathrm{~m}$. The climate is tropical wet with average temperature of $27^{\circ} \mathrm{C}$ and annual rainfall of 2800 $\mathrm{mm}$. The population of Tebing rambutan Village is 791, approximately $80 \%$ of whom (630) belongs to Semende tribe.

\section{Data collection}

Selecting key informants and gathering data of utilized plants

Six key informants were interviewed to get data on the plants commonly used by the villagers. The key informants were those considered having more knowledge of plants than ordinary residents. Interviewing key informants for gathering data is commonly done in ethnobotany studies (Tongco 2007). Each key informant was taken to the gardens to record plant names and their uses in tally sheets. Each plant was photographed. A total of 106 plant species were identified as being used by villagers.

\section{Selecting plants to be shown to respondents}

Of the 106 species used by villagers, a total of 50 species, representing each type of use were selected and their images were printed. Each species was shown in two pictures showing the whole plant and a close-up showing its characteristics.

\section{Selecting respondents}

Out of 630 villagers belonging to Semende tribe, 64 were selected as respondents to be interviewed. They consisted of 32 males and 32 females, 15-60 years old.

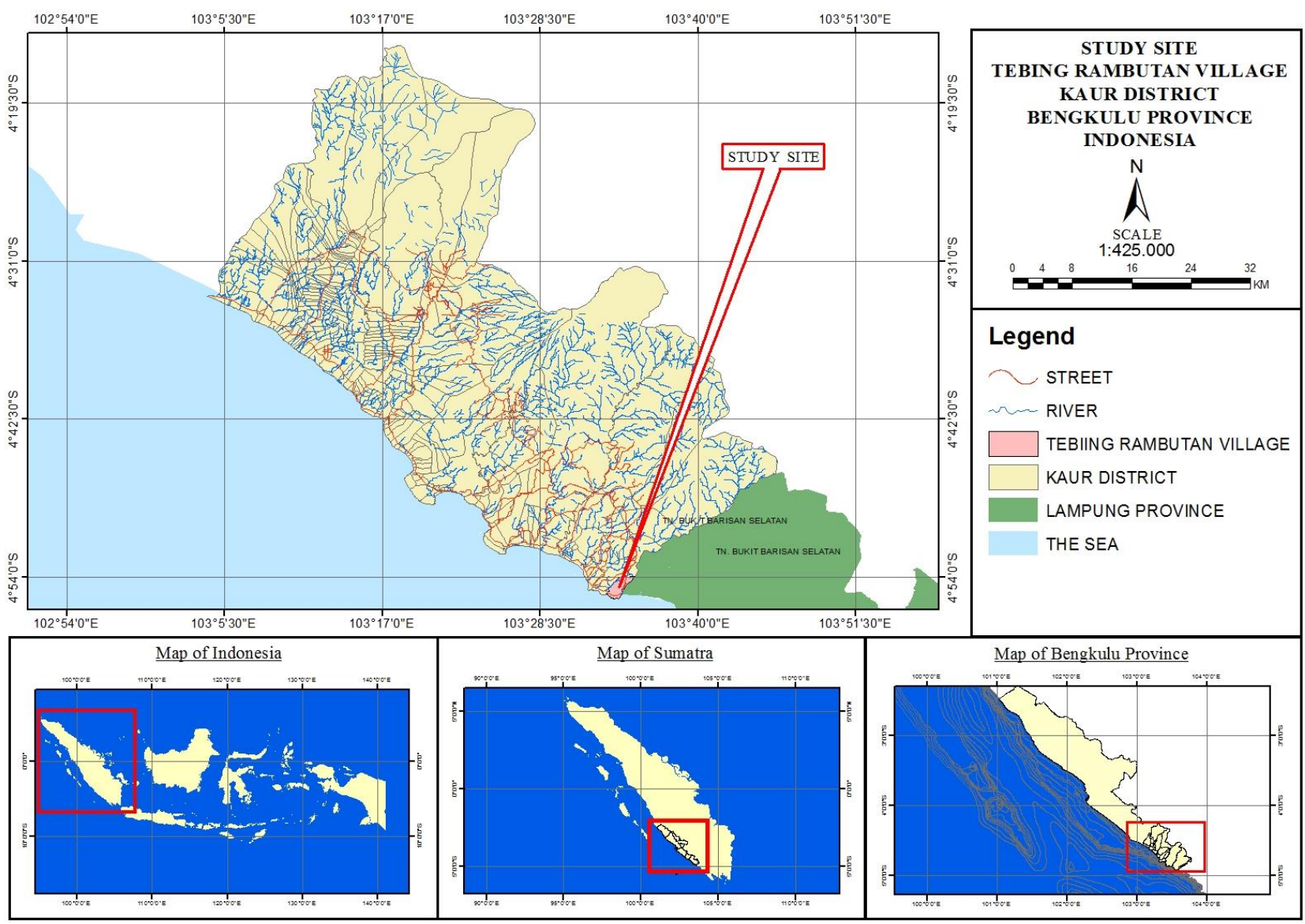

Figure 1. Study site, Tebing Rambutan Village, Nasal Sub-district, Kaur District, Bengkulu Province, Indonesia 


\section{Interviewing respondents}

The personal data of each respondent, namely age, gender, family profession, education, hobby, time spent in garden, and time spent enjoying electronic entertainment (using cellular phones, computers, and TVs) were collected through interview. Then, each respondent was asked to identify the names and uses of each species of plant in the photographs. Similar studies (Setalaphruk and Price 2007; Pilgrim et al. 2008; Wiryono and Nurliana 2011; and Wiryono et al. 2017) have also used photographs to test the ability of respondents to identify plants.

\section{Data analyses}

The species' names and uses were tabulated and analyzed descriptively. To determine whether the respondent's ability to recognize plant's names and uses were correlated with age, the regression analyses were performed, and to determine whether botanical knowledge was affected by gender, t-tests were conducted. All the statistical analyses were done in Microsoft Office Excel.

\section{RESULTS AND DISCUSSION}

\section{The diversity of species utilized by villagers}

According to interviews with key informants, 106 species of plants were used by the villagers of Tebing Rambutan for 14 types of uses (Table 1). This number was much higher than 48 species utilized by local people in Hiang Forest of Kerinci District, Jambi Province (Andesmora 2017), 65 species by villagers in Kabena Island, Southeast Sulawesi Province (Rahayu and Rugayah 2010), 75 species by Tanjung Terdana villagers of Central Bengkulu District (Wiryono et al. 2017), but lower than 163 species by villagers in Banten (Wardah 2003), 122 species by people of Cienda and San Vicente villagers on Leyte island of the Philippines (Langenberger et al. 2009). The number of locally used plant species in a village is determined by the diversity of plants species growing in the village and the local botanical knowledge of people.

The top three types of uses in this study were food (52 species), firewood (31) and medicine (30) (Figure 2). Food is essential for the survival of humanity. So, it is reasonable that the number of plant species for food was much higher than that for other uses. The species number of food plants also ranked first in Rajegwesi Village, Banyuwangi District, East Java (Pamungkas et al. 2013), among Baduy Dalam community in Banten (Wardah 2003) and in the community near Hiang Forest of Kerinci District, Jambi Province (Andesmora 2017). However, the number of food plant species in this study was much smaller than that among Karo ethnic group in North Sumatra, which was 109 species (Nisyawati et al. 2017), Baduy Dalam people in Banten, 81 (Wardah 2003), and Tengger community in Bromo Tengger Semeru National Park, East Java, 67 species (Batoro et al. 2013).

Firewood use ranked second in this study as it did in the community of Hiang Forest of Kerinci (Andesmora 2017) and in Tanjung Terdana Village of Central Bengkulu District (Wiryono et al. 2017). Plants for medicinal use ranked third in this study, consisting of 30 species, much lower than 181 medicinal plant species used by villagers Poncokusumo District of East Java (Batoro and Siswanto, 2017) and 127 medicinal plant species by people of Serampas tribe in Kerinci Seblat Jambi Province (Hariyadi and Ticktin 2012). The indigenous people near Gunung Halimun National Park used 147 species for medicine and cosmetics (Rahayu and Harada 2004), and the Tengger people in East Java used 120 species as medicines and poison (Batoro et al. 2013). These data indicate that rural people still practice traditional healing method using local plants.

\section{The correlation between botanical knowledge and age}

The botanical knowledge of Semende tribe people was not shared evenly among respondents' age classes (Figs 3 and 4). The elders knew more about plant names and uses than the young. The regression analyses showed that the age of respondent was positively correlated with his or her ability to identify plants $\left(\mathrm{R}=0.66 ; \mathrm{R}^{2}=0.43 ; \mathrm{p}\right.$-value $=$ 3.76E-09; Fig. 5) and to mention the plant uses $(\mathrm{R}=0.74$; $\mathrm{R}^{2}=0.55 ; \mathrm{p}$-value $=2.83$ E-12; Fig.6). These results indicated that there is a decline in TEK among the young generation. In another study in Tanjung Terdana Village of Central Bengkulu, Wiryono et al. (2017) also reported the same result. In Garifuna, Nicaragua, the young individuals knew much less about the use of plants than the elders (Coe and Anderson 1996). In Western Himalaya, only the elders (more than 40 years old) knew the medicinal uses of plants, while the young people were practically ignorant of that knowledge (Uniyal et al. 2006). In Sukamandi Village of Subang, West Java, older people could identify tree ferns better than the young (Suryana et al. 2018). The results of this study confirm that erosion of botanical knowledge among the young generation is a general trend worldwide (Ramirez 2007; Aswani et al. 2018).

Age itself is not a factor directly affecting botanical knowledge, but the age of a person is related to certain activities which affect his or her interaction with plants. In this study, we found that age was positively correlated with time spent in gardens (Table 2). The elders visited gardens longer than the young, implying that they had more intensive interaction with plants and thus became more familiar with plants than the young. Conversely, age was negatively correlated with time spent enjoying electronic entertainment (Table 4). It implied that young preferred playing with electronic gadget to spending their time in nature. Previously, in the US, there was a shift from naturebased to electronic-based recreation, leading to the decline of visits to forest parks or gardens (Pergams and Zaradic 2008). This alienation from nature is the real cause of botanical knowledge decline among young people. Many aspects of modernization may cause this alienation, such as education (Brosi et al 2007; Saynez-Vaquez et al. 2016), government programs which lead to the loss access of local communities to traditional resources (Turner and Turner 2008), and penetration of market economy (Godoy et al 2005; Gómez-Baggethun et al. 2010). The correlation between age and botanical knowledge is not always linear. In Kolo District of southeastern Niger, the 
knowledge of plant names increased with age until 50 years old (Ayantunde et al. 2008), then, after this age, the knowledge slightly declined, because the old men shifted the responsibilities of herding to the younger ones and they lost knowledge of vegetation.

Table 1. Species of plants used by the people of Semende tribe in Tebing Rambutan Village, Bengkulu, Indonesia

\begin{tabular}{|c|c|c|c|}
\hline Local names & Scientific names & Family & Types of uses \\
\hline Akar tuba & Derris elliptica Benth & Fabaceae & Poison \\
\hline Alpukat/pokat & Persea americana Mill. & Lauraceae & $\begin{array}{l}\text { Cosmetic, firewood, food, medicine, } \\
\text { shade }\end{array}$ \\
\hline Aren & Arenga pinnata (Wurmb) Merr. & Arecaceae & Food, handicraft \\
\hline Bambu/buluh & Bambusa sp & Poaceae & Construction, food, handicraft, hedge \\
\hline Bayam & Amaranthus sp & Amaranthaceae & Food, forage \\
\hline Bayur & Pterospermum javanicum Jungh. & Malvaceae & Construction, firewood \\
\hline Belimbing manis & Averrhoa carambola $\mathrm{L}$. & Oxalidaceae & Food, forage \\
\hline Belimbing wuluh & Averrhoa bilimbi L. & Oxalidaceae & Food, forage \\
\hline Brotowali & Tinospora crispa (L.) Miers ex Hoff.f & Menispermaceae & Medicine \\
\hline Bunga kemuning & Murraya paniculata (L.) Jack & Rutaceae & Ornament \\
\hline Bunga kertas & Zinia elegans $\mathrm{L}$. & Asteraceae & Ornament \\
\hline Bunga matahari & Helianthus annuus $L$ & Asteraceae & Food, ornament \\
\hline Bunga melati & Jasminum sambac (L) Aiton & Oleaceae & Custom, cosmetic \\
\hline Bunga terompet & Allamanda cathartica $\mathrm{L}$ & Apocynaceae & Ornament \\
\hline Cabe rawit & Capsicum frutescens $\mathrm{L}$ & Solanaceae & Spice \\
\hline Capit udang & Heliconia sp. & Heliconiaceae & Ornament \\
\hline Cengkeh & Syzygium aromaticum (L.) Merrill \& perry & Myrtaceae & Food, medicine \\
\hline Cocor air/cocor bebek mini & Kalanchoe tomentosa Baker & Crassulaceae & Ornament \\
\hline Cocor bebek & Kalanchoe pinnata ( Lam.) Pers & Crassulaceae & Medicine, ornament \\
\hline Damar & Shorea javanica Koord et Valeton & Dipterocarpaceae & Construction, firewood \\
\hline Daun bawang & Allium fistulosum $\mathrm{L}$ & Alliaceae & Food \\
\hline Duren/durian & Durio zibethinus Rumph. Ex Murray & Malvaceae & Construction, food, firewood \\
\hline Euphorbia & Euphorbia milii L. & Euphorbiaceae & Ornament \\
\hline Ganyong/laos & Canna discolor Lindl. & Cannaceae & Food, medicine \\
\hline Genjer & Limnocharis flava (L.) Buchenau & Limnocharitaceae & Food, forage \\
\hline Jabung & Erigeron sumatrensis Retz & Asteraceae & Medicine, ornament \\
\hline Jagung & Zea mays L. & Poaceae & Food, forage \\
\hline Jambu air & Syzygium aqueum (Burm.f.) Alston, & Myrtaceae & Construction, food \\
\hline Jambu keghas/jambu biji & Psidium guajava $\mathrm{L}$. & Myrtaceae & Food, firewood, medicine \\
\hline Jarak pagar & Jatropha curcas $\mathrm{L}$ & Euphorbiaceae & Hedge, medicine \\
\hline Jati & Tectona grandis L. f. & Lamiaceae & Construction, firewood \\
\hline Jengger ayam & Celosia cristata $\mathrm{L}$. & Amaranthaceae & Ornament \\
\hline Jengkol/jering & Archidendron pauciflorum (Benth.) I. C. Nielsen & Fabaceae & Food, firewood \\
\hline Jernang & Daemonorops draco (Willd.) BI. & Arecaceae & Color, medicine \\
\hline Jeruk manis & Citrus $x$ sinensis L. Osbeck & Rutaceae & Food, medicine \\
\hline Kacang panjang & Vigna unguiculata sesquipedalis (L.) Verdc & Fabaceae & Food, forage \\
\hline Kaktus centong & Opuntia cochenillifera $($ L.) Mill & Cactaceae & Ornament \\
\hline Kangkung & Ipomoea aquatica Forssk & Convolvulaceae & Food, forage \\
\hline Kapuk & Ceiba pentandra (L.) Gaertn. & Malvaceae & Construction, firewood, handicraft \\
\hline Karet & Hevea braziliensis Muell. Arg & Euphorbiaceae & Construction, firewood \\
\hline Kates/sangsile & Carica papaya $\mathrm{L}$. & Caricaceae & Cosmetic, food, forage, medicine \\
\hline Katuk & Sauropus androgynus (L). Merr & Phyllanthaceae & Food \\
\hline Kayu ress & Gliricidia sepium (Jacq.) Kunth ex Walp. & Fabaceae & Firewood, forage, hedge \\
\hline Kayu secang & Caesalpinia sappan $\mathrm{L}$. & Fabaceae & Medicine \\
\hline Kecipir/embing & Psophocarpus tetragonolobus (L.) D. C. & Fabaceae & Food, forage \\
\hline Kedondong & Spondias dulcis L. & Anacardiaceae & Food, firewood, forage, hedge \\
\hline Keladi & Aglaonema commutatum $\mathrm{L}$. & Araceae & Ornament \\
\hline Kelapa & Cocos nucifera $\mathrm{L}$. & Arecaceae & $\begin{array}{l}\text { Custom, food, firewood, hedge, } \\
\text { handicraft, medicine }\end{array}$ \\
\hline Kelengkeng & Dimocarpus longan Lour & Sapindaceae & Food, firewood, hedge \\
\hline Kencur & Kaempferia galanga $\mathrm{L}$. & Zingiberoideae & Medicine, spice \\
\hline Kol/kubis & Brassica oleracea var capitata $\mathrm{L}$. & Brassicaceae & Food, forage \\
\hline Kopi & Coffea sp. & Rubiaceae & $\begin{array}{l}\text { Cosmetic, firewood, food, hedge, } \\
\text { medicine }\end{array}$ \\
\hline Kumis kucing & Orthosiphon aristatus (Blume) Miq. & Lamiaceae & Medicine, ornament \\
\hline
\end{tabular}




\begin{tabular}{|c|c|c|c|}
\hline Kunyit & Curcuma longa $\mathrm{L}$. & Zingiberaceae & Color, medicine, spice \\
\hline Labu/kundur & Benincasa hispida Thunb & Cucurbitaceae & Food, forage \\
\hline Lada/sahang & Piper nigrum $\mathrm{L}$ & Piperaceae & Spice \\
\hline Lamtoro/petai cina & Leucaena leucocephala (Lamk.) de Wit, & Fabaceae & Construction, firewood, forage, \\
\hline Lengkuas & Alpinia galanga (L.) Willd & Zingiberaceae & Medicine, spice \\
\hline Lidah buaya & Aloe vera (L.) Burm.f. & Xanthorrhoeaceae & Cosmetic, medicine, ornament, \\
\hline Limau nipis & Citrus aurantifolia (Christm.) Swingle & Rutaceae & Cosmetic, custom, food, medicine, \\
\hline Lumay & Solanum nigrum $\mathrm{L}$ & Solanaceae & Food, forage \\
\hline Mangga & Mangifera indica $\mathrm{L}$ & Anacardiaceae & Construction, food, firewood \\
\hline Medang & Phoebe sp & Lauraceae & Construction, firewood, \\
\hline Medang gatal & Schima wallichii (DC.) Korth. & Theaceae & Construction, firewood, \\
\hline Melinjo/tangkil & Gnetum gnemon L. & Gnetaceae & Food, forage, firewood \\
\hline Mengkudu & Morinda citrifolia $\mathrm{L}$. & Rubiaceae & Medicine \\
\hline Merunggai/kelor & Moringa oleifera $\mathrm{L}$. & Moringaceae & Cosmetic, food, hedge, medicine \\
\hline Nanas & Ananas comosus ( L. ) Merr & Bromeliaceae & Food, medicine \\
\hline Nangka & Artocarpus heterophyllus Lamk. & Moraceae & Construction, food, firewood, \\
\hline Padi & Oryza sativa $\mathrm{L}$ & Poaceae & Food, forage \\
\hline Pakis haji & Cycas sp & Cycadaceae & Ornament \\
\hline Pandan hutan/pandan duri & Pandanus tectorius Parkinson ex Du Roi & Pandanaceae & Ornament \\
\hline Pandan wangi & Pandanus amaryllifolius Roxb & Pandanaceae & Color, custom, food, ornament \\
\hline Pepulut & Urena lobata $\mathrm{L}$. & Malvaceae & Medicine \\
\hline Pinang & Areca catechu $\mathrm{L}$. & Arecaceae & Custom, hedge, medicine, \\
\hline Pisang & Musa paradisiaca $\mathrm{L}$. & Musaceae & Custom, food, handicraft, medicine \\
\hline Pucuk merah & Syzygium myrtifolium ( Roxb. ) Walp & Myrtaceae & Hedge, ornament \\
\hline Puring & Codiaeum variegatum (L.) A. Juss. & Euphorbiaceae & Hedge, ornament, \\
\hline Rambutan & Nephelium lappaceum $\mathrm{L}$. & Sapindaceae & Construction, firewood, food \\
\hline Rayutan/rumput & Eleusine indica (L.) Gaertn & Poaceae & Forage \\
\hline Rimbang & Solanum torvum $\mathrm{Sw}$. & Solanaceae & Food \\
\hline Rotan & Calamus sp & Arecaceae & Hrcft \\
\hline Rumput gajah & Pennisetum purpureum Schumach. & Poaceae & Forage \\
\hline Rumput liar/ilalang & Imperata cylindrica (L.) Raeusch. & Poaceae & Forage \\
\hline Rumput raja & $\begin{array}{l}\text { Megathyrsus maximus (Jacq.) B.K. Simon \& } \\
\text { S.W.L. Jacobs }\end{array}$ & Poaceae & Forage \\
\hline Sawi & Brassica rapa subsp. Chinensis & Brassicaceae & Food, forage \\
\hline Sawit & Elaeis guineensis & Arecaceae & Food, forage \\
\hline Sawo & Manilkara zapota (L.) P. Royen & Sapotaceae & Firewood, food \\
\hline Sengon & Paraserianthes falcataria (L.) Nielsen & Fabaceae & Firewood, construction \\
\hline Serai/seghai & Cymbopogon citratus (DC.) Stapf, & Poaceae & Medicine, spice \\
\hline Seris/kersen & Muntingia calabura $\mathrm{L}$. & Muntingiaceae & Firewood, food \\
\hline Sirih & Piper betle $\mathrm{L}$. & Piperaceae & Custom, medicine \\
\hline Sirsak & Annona muricata $\mathrm{L}$ & Annonaceae & Firewood, food, medicine, \\
\hline Soka & Ixora siamensis $\mathrm{L}$. & Fabaceae & Ornament \\
\hline Sri rejeki & Aglaonema commutatum Schott & Araceae & Ornament \\
\hline Srikaya & Annona squamosa $\mathrm{L}$ & Annonaceae & Food, firewood, medicine \\
\hline Sukun & Artocarpus altilis (Parkinson) Forsk & Moraceae & Construction, firewood, food \\
\hline Tahi ayam & Tegetes erecta $\mathrm{L}$. & Asteraceae & Ornament, poison \\
\hline Talas & Colocasia esculenta ( L. ) Schott & Araceae & Food, forage, ornament \\
\hline Temulawak & Curcuma xanthorrhiza Roxb & Zingiberaceae & Cosmetic, medicine, spice \\
\hline Tenam & Anisoptera marginata Korth. & Dipterocarpaceae & Construction, firewood \\
\hline Terong/teghong & Solanum melongena $\mathrm{L}$. & Solanaceae & Food \\
\hline Tomat cung & Solanum lycopersicum $\mathrm{L}$. & Solanaceae & Food \\
\hline Ubi jalar & Ipomoea batatas L. & Convolvulaceae & Food, forage \\
\hline Ubi kayu/singkong & Manihot esculenta Crantz & Euphorbiaceae & Food, forage, firewood \\
\hline Waru & Hibiscus tiliaceus $\mathrm{L}$ & Malvaceae & Construction, firewood, hedge \\
\hline
\end{tabular}

Table 3. Correlations between variables related to botanical knowledge of Semende tribe

\begin{tabular}{lcccc}
\hline Variables correlated & P-value & R & $\mathbf{R}^{\mathbf{2}}$ & Equation \\
\hline Age (X) and time spent in gardens (Y) & $4.29 \mathrm{E}-14$ & 0.78 & 0.60 & $\mathrm{Y}=0.81-16.74$ \\
Age (X) and time spent enjoying electronic entertainment & $4.59 \mathrm{E}-17$ & 0.86 & 0.68 & $\mathrm{Y}=-0.56+29.95$ \\
Time spent in gardens (X) and number of species known (Y) & $4.51 \mathrm{E}-07$ & 0.58 & 0.34 & $\mathrm{Y}=0.26+36.17$ \\
Time spent in gardens (X) and number of uses known (Y) & $2.40 \mathrm{E}-07$ & 0.59 & 0.35 & $\mathrm{Y}=0.75+59.84$ \\
\hline
\end{tabular}




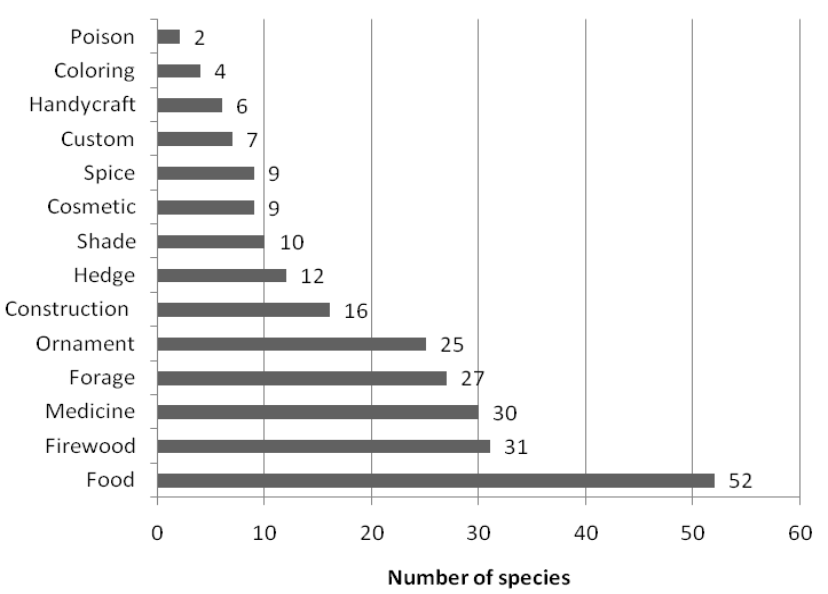

Figure 2. The number of plant species for each type of use

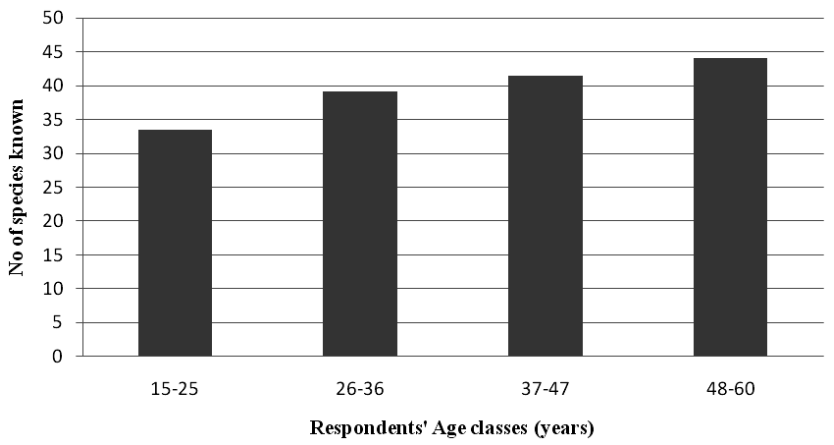

Figure 3. The number of species successfully identified by respondents according to age classes

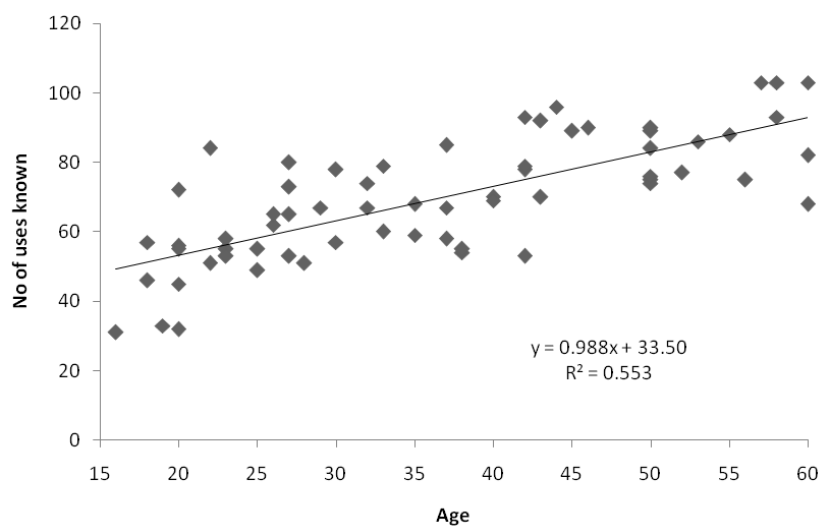

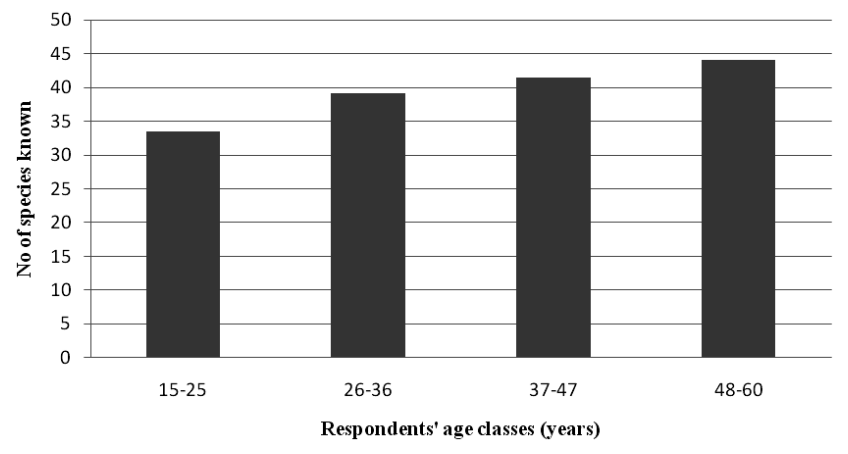

Figure 4. The number of plant uses recognized by respondents according to age classes

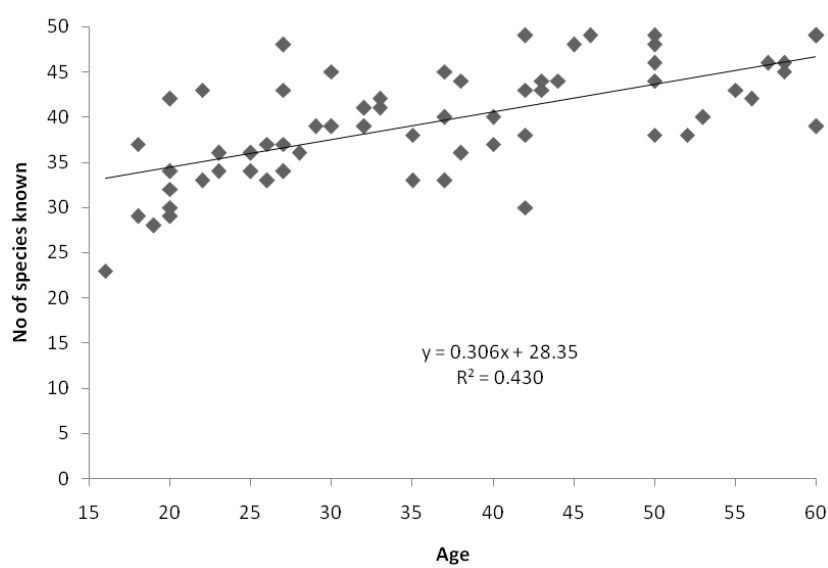

Figure 5. Correlation between the respondent's ability to identify plants (number of species identified) and his or her age

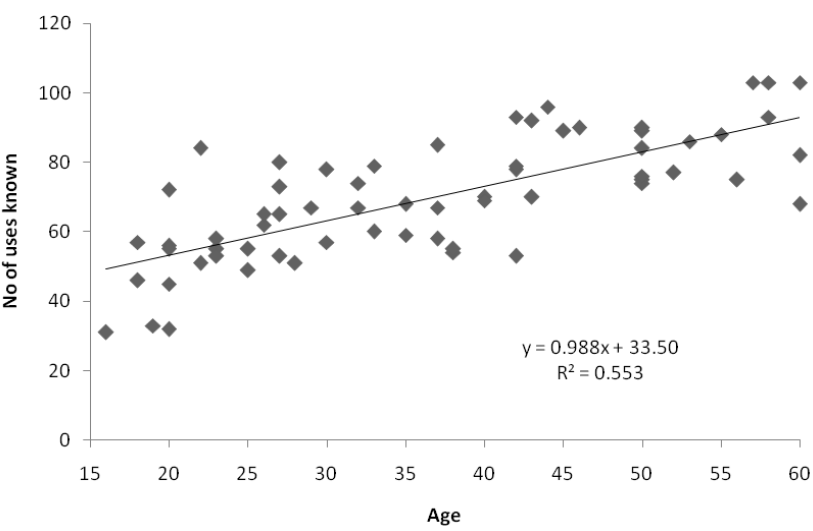

Figure 6. Correlation between the respondent's knowledge of plant uses (number of plant uses known) and his or her age

The botanical knowledge can be maintained among young people if they are involved in activities which give them opportunities to interact with plants. In the Andean Highland of Peru and Bolivia, the young did not lose knowledge of medicinal plants (Mathez-Stiefel et al. 2012) because the people in these two regions transferred their knowledge of medicinal plants to their children through teaching or giving the children opportunities to watch the families' use of medicinal plants. In New York, young people who migrated from the Dominican Republic still maintained knowledge of edible medicinal plants because they continued consuming those plants (Vandebroek and Balick 2012). 
Table 4. The number of species and plant uses identified by males and females and the time spent in garden and for electronic entertainment by males and females

\begin{tabular}{lrr}
\hline Variables compared & Males & Females \\
\hline Number of plant species known & $42.18 \mathrm{~b}$ & $36.87 \mathrm{a}$ \\
Number of plant uses known & $75.00 \mathrm{~b}$ & $64.06 \mathrm{a}$ \\
Time spent in gardens (hours/week) & $17.56 \mathrm{~b}$ & $8.31 \mathrm{a}$ \\
Time spent enjoying electronic & $7.97 \mathrm{a}$ & $10.87 \mathrm{~b}$ \\
entertainment (hours/week) & & \\
\hline
\end{tabular}

Note: numbers in the same row followed by different letter were significantly different at $5 \%$ significant level.

Table 5. The number of species successfully identified by respondents according to their level of education

\begin{tabular}{lcc}
\hline \multicolumn{1}{c}{ Education level } & $\begin{array}{c}\text { Average } \\
\text { age }\end{array}$ & $\begin{array}{c}\text { Average } \\
\text { number of } \\
\text { species } \\
\text { identified }\end{array}$ \\
\hline Not finishing elementary school & 58.33 & 43.67 \\
Finishing elementary school & 49.97 & 43.03 \\
Finishing junior high school & 36.88 & 39.76 \\
Finishing senior high school & 26.35 & 35.87 \\
\hline
\end{tabular}

\section{The effect of gender on botanical knowledge}

The males of Semende tribe, in this study, knew more plant names and uses than the females (Table 4). Like age, gender itself is not a factor directly affecting botanical knowledge, but in many communities, males and females have different roles which in turn affect the intensity of their interaction with plants. Therefore, in some communities males may have better botanical knowledge than females, but the opposite of this situation may occur in other communities. In western Himalaya, Uniyal et al. (2006) reported that males knew medicinal plants better than females because in the local communities, women had more household obligation, limiting their time for interacting with medicinal plants in the field. In southwestern Niger (Ayantunde et al. 2008), males had better ability in identifying forage, construction and firewood plants than women, but there was no difference in identifying medicinal and food plants between males and females. Meanwhile, in Garifuna, Nicaragua, males knew field crops and wild plants better than females, but females were more knowledgeable of food and medicinal plants than males because women were the health providers for the family (Coe and Anderson 1996)

Like in Garifuna, in rural communities near Chapada Diamantina National Park in Bahia, Brasil, women also knew more medicinal plants than men (Voeks 2007) because women's jobs were taking care of family health and maintaining the swiddens and homegardens. In a Caribbean horticultural village, Quilan and Quinlan (2007) also found that women knew more medicinal plant species than men. Meanwhile, several studies in Bengkulu Province, Wiryono and Nurliana (2011); Putra et al. (2012); Wiryono et al. (2017) and in Brazil, Sousa et al. (2012) did not find differences in botanical knowledge between males and females. Sometimes, there is an interaction between age and gender. In Boumba, Niger, the knowledge of food plants increased with age only for women (Muller et al. 2015).

\section{Education and local botanical knowledge}

The effect of education was not tested statistically in this study because the number of respondents was not evenly distributed among levels of education. However, the data in Table 5 shows that the ability to names plants decreased with increasing education level. In another study in Pohnpei, Micronesia, Brosi et al. (2007) found that western education contributed to the loss of botanical knowledge among the community. Likewise, in the Zapotec indigenous community in Mexico, botanical knowledge was negatively correlated with number of years of education (Saynes-Vásquez et al. 2016). In Samburu of northern Kenya, students knew less botanical knowledge than herders of the same age, because the students had less exposure to plants in nature than the herders who spent a lot of time in nature tending livestock (Bruyere at al. 2016).

In this study, the level of respondents' education was inversely correlated with age. Those who finished senior high school were the youngest among the respondents and they knew the least number of species, so the correlation between botanical knowledge and education may be similar to that between botanical knowledge and age. Presumably, it was the less time spent in the gardens which were responsible for the low number of species identified by those who finished senior high school.

In conclusion, we found erosion of botanical knowledge among the young people of Semende tribe. In order to maintain botanical knowledge among young people, there should be deliberate programs from the government and non-governmental organizations which bring the young people to gardens so they become aware of the local natural resources, especially plants.

\section{ACKNOWLEDGEMENTS}

We express our sincere gratitude to the Institute of Research and Community Services of the University of Bengkulu, Indonesia which provided fund for this study.

\section{REFERENCES}

Aiona K, Balick M J, Bennett BC, Bridges K, Burney DA, Burney LP, et al. 2007. Ethnobotany, the science of survival: a declaration from Kaua'i. Econ Bot 61 (1) : 1-2.

Andesmora EV, Muhadiono, Hilwan I. 2017. Ethnobotany Hiang Indigenous Forest, Kerinci. J. Trop. Life. Science 7 (2): 95-101.

Aswani S, Lemahieu A, Sauer WHH. 2018. Global trends of local ecological knowledge and future implications. PLoS ONE 13 (4): e0195440. DOI: 10.1371/journal.pone.0195440

Ayantunde AA, Briejer M, Hiernaux P, et al. 2008. Botanical Knowledge and its Differentiation by Age, Gender and Ethnicity in Southwestern Niger. Hum Ecol 36: 881. DOI: 10.1007/s10745008-9200-7

Batoro J, Setiadi D, Chikmawati T, Purwanto Y. 2013. Pengetahuan Tentang Tumbuhan Masyarakat Tengger di Bromo Tengger Semeru Jawa Timur. Jurnal Wacana 14 (1) 1-10. [Indonesian] 
Batoro J, Siswanto D. 2017. Ethnomedicinal survey of plants used by local society in Poncokusumo district, Malang, East Java Province, Indonesia. Asian J Med Biol Res 3 (2): 158-167; DOI: 10.3329/ajmbr.v3i2.33563

Berkes F. 1993. Traditional ecological knowledge in perspective. In Inglis JT (ed.). Traditional ecological knowledge: concepts and cases. Ecological Knowledge and International Development Research Centre, Ottawa.

Brosi BJ, Balick MJ, Wolkou R, Lee R, Kostka M, et al. 2007. Cultural erosion and biodiversity: Canoe-making knowledge in Pohnpei, Micronesia. Conserv Biol 21: 875-879.

Bruyere BL, Trimarco J, Lemungesi S. 2016. A comparison of traditional plant knowledge between students and herders in northern Kenya. J Ethnobiol Ethnomed 12: 48. DOI 10.1186/s13002-016-0121-Z

Coe FG, Anderson GJ. 1996. Ethnobotany of the Garifuna of Eastern Nicaragua. Econ Bot 50: 71-107.

Cuadra VP, Cambi V, Ruda MA, et al. 2012. Consequences of the Loss of Traditional Knowledge: The risk of injurious and toxic plants growing in kindergartens. Ethnobot Res Appl 10: 77-94.

Drew JA, Henne AP. 2006. Conservation biology and traditional ecological knowledge: integrating academic disciplines for better conservation practice. Ecol Soc 11 (2): 34

Gómez-Baggethun E, Mingorria S, Reyes-García V, Calvet L, Montes C. 2010. Traditional ecological knowledge trends in the transition to a market economy: empirical study in the Doñ ana natural areas. Conserv Biol 24: 721-729.

Godoy R, Reyes-Garc'ia V, Byron E, Leonard WR, Vadez V. 2005. The effect of market economies on the well-being of indigenous people and on their use of renewable natural resources. Annu Rev Anthr 34: 121-138. DOI: 10.1146/annurev.anthro.34.081804.120412.

Gómez-Baggethun E, Reyes-García V. 2013. Reinterpreting change in traditional ecological knowledge. Hum Ecol 41: 643-647

Hariyadi B, Ticktin T. 2012. Uras: Medicinal and Ritual Plants of Serampas, Jambi Indonesia. Ethnobot Res Appl 10: 133-149

Jocelyn G. Muller, Riyana Boubacar, Iro Dan Guimbo. 2015. The "How" and "Why" of Including Gender and Age in Ethnobotanical Research and Community-Based Resource Management. AMBIO 2015, 44: 67-78. DOI 10.1007/s13280-014-0517-8

Kai Z, Woan TS, Jie L, Goodale E, Kitajima K, et al. 2014. Shifting Baselines on a Tropical Forest Frontier: Extirpations Drive Declines in Local Ecological Knowledge. PLoS ONE 9 (1): e86598. DOI: 10.1371/journal.pone. 0086598

Langenberger G, Prigge V, Martin K, Belonias B, Sauerborn J. 2009. Ethnobotanical knowledge of Philippine lowland farmers and its application in agroforestry. Agrofor Syst 7: 173-194.

Mathez-Stiefel SL, Brandt R, Lachmuth S, et al. 2012 Are the young less knowledgeable? Local knowledge of natural remedies and its transformations in the Andean Highlands. Hum Ecol 40: 909. DOI: 10.1007/s10745-012-9520-5

Nisyawati, Aini RN，Silalahi M，Purba EC，Avifah N. 2017. The local knowledge of food plants used by Karo ethnic in Semangat Gunung Village, North Sumatra, Indonesia. AIP Conference Proceedings 1862, 030102 (2017); DOI: 10.1063/1.4991206.

Pamungkas RN, Indriyani S, Luchman Hakim L. 2013. The ethnobotany of homegardens along rural corridors as a basis for ecotourism planning: a case study of Rajegwesi village, Banyuwangi, Indonesia. J Biodiv Environ Sci 3 (8): 60-69.

Pergams ORW, Zaradic PA. 2008. Evidence for a fundamental and pervasive shift away from nature-based recreation. Proc Natl Acad Sci USA 105 (7): 387-393.

Pilgrim SE, Cullen LC, Smith DJ, Pretty J. 2008. Ecological knowledge is lost in wealthier communities and countries. Environ Sci Technol 42 (4): 1004-1009.
Putra RA, Wiryono, Aprianto E. 2012. Studi Etnobotani Suku Serawai di Kelurahan Sukarami Kecamatan Selebar Kota Bengkulu. Naturalis 1 (3): 214-224. [Indonesian]

Quinlan MB, Quinlan RT. 2007. Modernization and medicinal plant knowledge in a Caribbean horticultural village. Med Anthropol Q, New Ser 21 (2): 169-192.

Rahayu M, Harada K. 2004. Peran tumbuhan dalam kehidupan tradisional masyarakat lokal di Taman Nasional Gunung Halimun Jawa Barat. Berita Biologi 7 (1): 17-23 . [Indonesian]

Rahayu M, Rugayah. 2010. Local knowledge and utilization of plants by local communities Kabaena Island, Southeast Sulawesi. Berita Biologi 10 (1): 67-75. [Indonesian]

Ramirez CR. 2007. Ethnobotany and the loss of traditional knowledge in the $21^{\text {st }}$ century. Ethnobot Res Appl 5: 245-247.

Rist L, Shanker RU, Milner-Gulland EJ, et al. 2010. The use of traditional ecological knowledge in forest management: an example from India. Ecol Soc 15 (1): 3.

Saynes-Vásquez A, Vibrans H, Vergara-Silva F, Caballero J. 2016. Intracultural Differences in Local Botanical Knowledge and Knowledge Loss among the Mexican Isthmus Zapotecs. PLoS ONE 11 (3): e0151693. DOI: 10.1371/journal.pone.0151693

Setalaphruk C, Price LL. 2007. Children's traditional ecological knowledge of wild food resources: a case study in a rural village in Northeast Thailand. J Ethnobiol Ethnomed 3: 33-44.

Sousa RdS, Hanazaki N, Lopes JB, de Barros RFM. 2012 Are Gender and Age Important in understanding the Distribution of Local Botanical Knowledge in Fishing Communities of the Parnaíba Delta EnvironmentalProtection Area? Ethnobot Res Appl 10: 551-559.

Suryana, Iskandar J, Parikesit, Partasasmita R. 2028. Ethnobotany of tree ferns in Pasir Menyan Hamlet, Sukamandi Village Subang, West Java, Indonesia. Biodiversitas 19 (6): 2044-2051

Tongco Ma.D. 2007. Purposive sampling as a tool for informant selection. Ethnobot Res Appl 5: 147-158.

Turner NJ, Turner KL. 2008. "Where our women used to get the food": Cumulative effects and loss of ethnobotanical knowledge. Botany 86 : 103-115.

Uniyal SK, Singh KN, Jamwal P, Lal B. 2006. Traditional use of medicinal plants among the tribal communities of Chhota Bhangal, Western Himalaya. J Ethnobiol Ethnomed 2: 14

Uprety Y, Asselin H, Bergeron Y, et al. 2012. Review article Contribution of traditional knowledge to ecological restoration: Practices and applications. Écoscience 19 (3): 224-237

Vandebroek I, Balick MJ. 2012. Globalization and loss of plant knowledge: Challenging the paradigm. PLoS ONE 7 (5): e37643. DOI: 10.1371/journal.pone.0037643

Voeks. 2007. Are women reservoirs of traditional plant knowledge? Gender, ethnobotany and globalization in Northeast Brazil. Singapore J Trop Geogr 28: 7-20.

Wardah. 2003. Pemanfaatan keanekaragaman sumberdaya tumbuhan oleh masyarakat Badudy Dalam sekitar Gunung Kendeng Selatan, Kabupaten Lebak, Banten. Berita Biologi 5 (6): 679-689.

Wiryono, Japriyanto, Erniwati. 2017. The diversity of locally utilized plants and local botanical knowledge in Central Bengkulu District, Bengkulu Province, Indonesia. Biodiversitas 17 (2): 1589-1595.

Wiryono, Lipranto. 2013. The diversity of locally useful species Batu Ampar village near Bukit Raja Mandara protected forest area in South Bengkulu District. Jurnal Manusia dan Lingkungan 20 (2): 119-127.

Wiryono, Nurliana S. 2011. The knowledge of Bengkulu University's forestry students of tree diversity in their campus. Nusantara Biosci 22: 98-103.

Wiryono, Puteri VNU, Senoaji G. 2016. The diversity of plant species, the types of plant uses and the estimate of carbon stock in agroforestry system in Harapan Makmur Village, Bengkulu, Indonesia. Biodiversitas 7 (1) : 249-255. 